\title{
Toxic effects of cannabis and cannabinoids: Animal data
}

\author{
Pierre Beaulieu MD PhD FRCA
}

P Beaulieu. Toxic effects of cannabis and cannabinoids: Animal data. Pain Res Manage 2005;10(Suppl A):23A-26A.

\begin{abstract}
The present article reviews the main toxic effects of cannabis and cannabinoids in animals. Toxic effects can be separated into acute and chronic classifications. Acute toxicity studies show that it is virtually impossible to die from acute administration of marijuana or tetrahydrocannabinol, the main psychoactive component of cannabis. Chronic toxicity involves lesions of airway and lung tissues, as well as problems of neurotoxicity, tolerance and dependence, and dysregulations in the immune and hormonal systems. Animal toxicity data, however, are difficult to extrapolate to humans.
\end{abstract}

Key Words: Animal; Cannabinoids; Cannabis; Toxicity

\section{Effets toxiques du cannabis et des cannabi- noïdes : données d'études sur animal}

Le présent article passe en revue les principaux effets toxiques du cannabis et des cannabinoïdes chez les animaux. On peut classer les effets toxiques en deux catégories : aigus et chroniques. Selon les études de toxicité aiguë, il est presque impossible de mourir d'une surdose de marijuana ou de tétrahydrocannabinol, principal composant psychoactif du cannabis. La toxicité chronique, de son côté, est associée à des lésions des voies aériennes et des poumons, ainsi qu'à la neurotoxicité, tolérance et dépendance, et à la dysrégulation des systèmes immunitaire et hormonal. Il est cependant difficile d'appliquer aux humains les données sur la toxicité animale.
Since its use in ancient times for therapeutic purposes, $\checkmark$ cannabis has been known to produce deleterious effects. The adverse effects of cannabis in humans are reviewed in the present supplement to Pain Research 83 Management (1). Acute effects of cannabis and cannabinoids are well established, while some uncertainties exist with regard to its long-term effects (2). However, as is often the case with cannabis, results of various studies can be interpreted differently depending on the author; for example, some authors may concentrate on the existence of toxic effects, while others may insist that these effects are minor (2). Overall, the most appropriate opinion on the use of medical marijuana may come from the United States Institute of Medicine when they stated that "except for the harms associated with smoking, the adverse effects of marijuana use are within the range of effects tolerated with other medications" (3).

It has been suggested that there are 426 chemical entities in the marijuana plant, of which more than 60 are cannabinoids (4). Therefore, it is not surprising that some of these substances can exert adverse effects. Hundreds of studies, starting in the 1970s, have been published on the toxicity of cannabinoids in animals, and it is well beyond the scope of the present article to review them all. We will only concentrate on key animal data regarding the acute and chronic toxic effects of cannabis and cannabinoids. One must keep in mind that most of the animal studies performed have used delta-9-tetrahydrocannabinol (THC) injections of $10 \mathrm{mg} / \mathrm{kg}$ to $20 \mathrm{mg} / \mathrm{kg}$, whereas, for an average adult of $70 \mathrm{~kg}$ smoking a cigarette containing $15 \mathrm{mg}$ of THC, this corresponds to an administration of $40 \mu \mathrm{g} / \mathrm{kg}$ of THC (5).

\section{ACUTE TOXICITY}

In animals, the administration of high doses of THC, other cannabinoids or endogenous cannabinoids (endocannabinoids) such as anandamide, produces a typical response characterized by hypothermia, hypolocomotion, catalepsia and antinociception. From studies in knockout animals, it has been shown that the cannabinoid receptor $\mathrm{CB}_{1}$ is responsible for these effects (6).

The overall acute toxicity of THC is low. The mean lethal dose (that which kills $50 \%$ of animals) of oral THC in rats is $800 \mathrm{mg} / \mathrm{kg}$ to $1900 \mathrm{mg} / \mathrm{kg}$ depending on sex and strain (7). Animal studies have shown a very large separation (by a factor of more than 10,000) between pharmacologically effective and lethal doses (8). Furthermore, no cases of death were reported following maximum THC oral doses of up to $3 \mathrm{~g} / \mathrm{kg}$ and $9 \mathrm{~g} / \mathrm{kg}$ in dogs and monkeys, respectively (8). However, monkeys treated acutely with $128 \mathrm{mg} / \mathrm{kg}$ or more intravenously, died from respiratory arrest and cardiac failure, whereas all monkeys survived with doses of $92 \mathrm{mg} / \mathrm{kg}$ or less (9).

Phillips et al (10) investigated the acute toxicity of pure THC in rats and mice (Table 1). Both rats and mice became ataxic $1 \mathrm{~min}$ to $2 \mathrm{~min}$ after having received an intravenous injection of THC. If stimulated, they became hyperactive for $1 \mathrm{~s}$ to $2 \mathrm{~s}$. The righting reflex was lost and dyspnea progressed to death by respiratory depression. Postmortem examination revealed that all organs (except the lungs, which were congested and edematous) were unremarkable. Survivors were free of toxic signs after $24 \mathrm{~h}$ to $72 \mathrm{~h}$.

In rodents, low doses of cannabinoids decrease locomotor activities, while higher doses stimulate movements and even higher doses lead to catalepsy (11). Similarly, in mice, Adams and Martin (12) describe a 'popcorn effect' in animals treated with THC (sedation associated with a jump in response to a stimulus wthat, in turn, triggers another stimulation and the jump of another mouse, etc). Furthermore, cannabinoids cause an increase in gait width (13) and show rotarod 
TABLE 1

Dose range of delta-9-tetrahydrocannabinol administered by different routes in animals to produce various effects

\begin{tabular}{|c|c|c|c|c|c|c|c|c|c|}
\hline & $\begin{array}{l}\text { Spontaneous } \\
\text { activity re }\end{array}$ & $\begin{array}{l}\text { Decreased } \\
\text { ectal temperature }\end{array}$ & Antinociception & Catalepsy & $\mathrm{LD}_{50}$ & $\begin{array}{c}\text { Drug } \\
\text { discrimination }\end{array}$ & $\begin{array}{l}\text { Static } \\
\text { ataxia }\end{array}$ & $\begin{array}{c}\text { Operant } \\
\text { suppression }\end{array}$ & Mortality \\
\hline & & & & & $482 \mathrm{mg} / \mathrm{kg}$ (orally) & & & & \\
\hline & \multicolumn{9}{|c|}{$800-1900 \mathrm{mg} / \mathrm{kg}$ (orally) } \\
\hline Dog & - & - & - & - & - & \multicolumn{3}{|c|}{$0.2 \mathrm{mg} / \mathrm{kg}$ (iv) } & $\begin{array}{l}\text { No deaths after doses } \\
\text { up to } 3 \mathrm{~g} / \mathrm{kg} \text { (orally) }\end{array}$ \\
\hline
\end{tabular}

Data from Forney (18), Thompson et al (9), and Phillips et al (10). ip Intraperitoneally; iv Intravenously; $L D_{50}$ Lethal dose (that which kills $50 \%$ of animals)

impairments in mice after direct injection of synthetic cannabinoids into the cerebellum (14).

Low doses of THC or other psychotropic cannabinoids produce a combination of sedative and stimulant effects, whereas higher doses are mainly sedative (15). Animal studies have also found that THC and anandamide cause deficits in shortterm memory in spatial learning tasks (16). These effects are reversed by a cannabinoid $\mathrm{CB}_{1}$ antagonist. In addition, cannabinoids and endocannabinoids reduce motor activity, reduce body temperature, decrease reflex responses and muscle tone, impair the ability to carry out complex behaviour and decrease overt aggressive behaviour, especially in primates for the latter.

In isolated heart, THC produces a biphasic effect on heart rate with an initial increase followed by a decrease. THC also decreases coronary blood flow and cardiac contractile force (17). In the whole animal (dogs, cats and rats), THC produces a decrease in blood pressure associated with bradycardia, but these effects may vary with other species. Milzoff et al (cited by Forney [18]) have studied the effects of THC on heart rate, respiratory rate and body temperature in anesthetized rats after doses of $0.625 \mathrm{mg} / \mathrm{kg}$ to $10 \mathrm{mg} / \mathrm{kg}$. They have reported decreases in all the parameters measured.

Finally, in rodents, THC and, to a lesser degree, other cannabinoids, such as nabilone and cannabinol, reduce intestinal motility by a $\mathrm{CB}_{1}$ receptor-mediated mechanism (19).

\section{CHRONIC TOXICITY}

A great number of chronic and potentially toxic effects of cannabis on various systems have been described.

\section{Lung toxicity}

Animals exposed to varying doses of marijuana smoke for 12 to 30 months show extensive damage to the smaller airways as well as acute and chronic pneumonia. However, rats exposed to marijuana smoke for one year failed to demonstrate any anatomical or functional evidence of emphysema (20).

\section{Neurotoxicity}

Although the presumed neurotoxic effects of marijuana enter into the legalization argument, surprisingly few experimental studies of marijuana toxicity have been published, at least until recently. Several laboratories have reported that chronic exposure to THC or marijuana extracts persistently alters the structure and function of the rat hippocampus, a paleocortical brain region involved with learning and memory processes (21). It is suggested that both age during exposure and duration of exposure may be critical determinants of neurotoxicity.

Periods of cannabis or THC exposure shorter than three months have not yet been demonstrated to produce neurotoxic effects in rats (21). Studies of monkeys with up to 12 months of daily exposure have not consistently reported neurotoxicity, although one must keep in mind that it represents less time of exposure for these animals compared with rats (lifespan of approximately 40 years for monkeys compared with two to three years for rats).

Studies of the effects of cannabinoids on neurons in vitro have yielded inconsistent results. Indeed, the mixed reports of neurotoxic and neuroprotective effects of cannabinoids are confusing (22) (Figure 1)

\section{TOLERANCE AND DEPENDENCE}

Phillips et al (10) administered THC to rats intraperitoneally for 30 days at five dose levels ranging from $0 \mathrm{mg} / \mathrm{kg}$ to $30 \mathrm{mg} / \mathrm{kg}$. Animals displayed signs of increasing ataxia, lacrimation, diarrhea and depression. There was no evidence of developing tolerance, although Carlini (23) has reported that rats can develop tolerance to the behavioural effects of THC when low doses are administered over a short period of time.

Tolerance to the biological effects of THC has been demonstrated in cultured cells and animal species. Using the $\mathrm{CB}_{1}$ receptor antagonist SR141716A, a withdrawal syndrome can be produced in rats, mice and dogs that have been maintained on THC (24). The syndrome includes scratching, licking, arched back and ptosis. However, there is no animal model of cannabis dependence because animals do not typically selfadminister cannabis in the same way as they do with opioids, cocaine or alcohol (24).

\section{IMMUNE SYSTEM}

Cell and animal experiments have shown that THC exerts complex effects on humoral and cellular immunity (25). Cannabinoids and endocannabinoids can be considered immunomodulators that have an influence on almost every component of the immune response machinery. Generally, 
endocannabinoids exert a negative action on the onset of a variety of parameters of the immune response, although their role in normal immune homeostasis and the development of immune system disorder is still far from being resolved (25).

Guinea pigs and mice have been used extensively as experimental models for documenting the effects of cannabinoids (THC doses in the range of $0.2 \mathrm{mg} / \mathrm{kg}$ to $100 \mathrm{mg} / \mathrm{kg}$ ) on host resistance in the intact animal. It was established that THC has the potential to compromise host resistance to both viruses and bacteria (26). Furthermore, Mishkin and Cabral (27) have demonstrated that the decreased antiviral responsiveness is paralleled by decreased cellular and humoral immunity, suggesting that THC targets specific elements of the immune system involved in antivirus responses.

In vitro studies have also demonstrated that cannabinoids alter the functional activities of a variety of immune cell types (28). However, at present, there are no definitive data that demonstrate that these in vitro cellular effects are operative in humans (26).

\section{CANCER}

The antineoplastic activities of THC and its analogue were first observed in the early 1970s (29). Based on the immunosuppressive effects of cannabis, animal studies were originally performed to investigate the possibility that marijuana smoking, or long-term THC treatment, might favour tumour growth. These studies, however, initially produced contradictory results. The data of one study suggested that the growth of a lung carcinoma was enhanced due to $\mathrm{CB}_{2}$ receptor-mediated immune suppression (30). However, in a two-year administration of high oral doses $(50 \mathrm{mg} / \mathrm{kg}$ ) of THC to rats and mice, Chan et al (31) showed that THC treatment tended to increase survival $(70 \%$ in the treated animals compared with $45 \%$ in the untreated controls) and lower the incidence of primary tumours with no marked histopathological alterations in the brain or other organs. Indeed, it is now a fact that cannabinoids inhibit tumour growth in laboratory animals by modulating key cell signalling pathways, thereby inducing direct growth arrest and the death of tumour cells, as well as by inhibiting tumour angiogenesis and metastasis (32). Thus, cannabinoids are selective antitumour compounds that kill tumour cells without affecting their nontransformed counterparts.

Therefore, cannabinoids are potential anticancer agents, which appear to be well tolerated in animal studies and which do not produce the generalized toxic effects in normal tissues that limit most conventional agents used in chemotherapy (33).

\section{HORMONAL SYSTEM AND FERTILITY}

Cannabis and THC act on the hypothalamic-pituitary adrenal axis. In animal studies, a multitude of endocrine processes are influenced by these drugs, including adrenocorticotropic hormone, thyroid-stimulating hormone and growth hormone. Indeed, the administration of cannabinoids decreases plasma growth hormone levels, reduces serum thyroid-stimulating hormone levels (by $90 \%$ within 60 min of treatment in rats) and stimulates the release of adrenocorticotropic hormone and glucocorticoids (34). Thus, the regulation of blood glucose levels may be affected.

THC has been reported to account for the majority of the reproductive hazards of marijuana use. Animal studies in males largely confirm the ability of cannabinoids to suppress

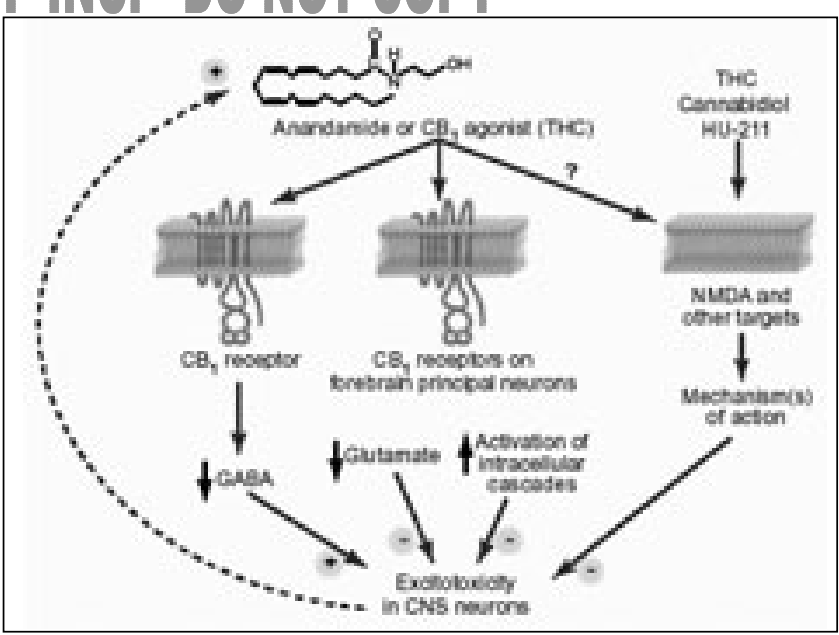

Figure 1) Dual effect of cannabinoids on neurons. Cannabinoids may lead to opposite effects on neuron survival/death. Stimulation of cannabinoid receptors located on brain neurons $\left(\mathrm{CB}_{1}\right)$ provides protection against excitotoxicity (through inhibition of glutamate release and activation of intracellular signalling cascades) or augmentation of excitotoxicity (by decreasing gamma aminobutyric acid [GABA] release from GABAergic inhibitory interneurons). Finally, cannabinoids may exert their neuroprotective effects via a third mechanism which does not involve $\mathrm{CB}_{1}$ receptors. CNS Central nervous system; NMDA N-methylD-aspartate; THC Delta-9-tetrahydrocannabinol. Reproduced with permission from Mechoulam and Lichtman (22)

spermatogenesis, to induce aberrations in sperm morphology (35), to reduce the weight of reproductive organs and to decrease the plasma concentration of hormones such as testosterone (an acute dose of THC produces a $65 \%$ reduction in plasma testosterone levels by $60 \mathrm{~min}$ in the rhesus monkey) (36). These studies suggest that THC inhibits luteinizing hormone and follicle-stimulating hormone secretion, consequently decreasing testosterone production and altering spermatogenesis (34). High THC doses cause a modest increase in abnormally formed sperm $(5.3 \%$ in mice treated with $10 \mathrm{mg} / \mathrm{kg}$ of THC per day for five days compared with $1.5 \%$ in controls) (35). In females, THC prolongs the estrous cycle and decreases the proestrous surge of luteinizing hormone inhibiting ovulation (37). Acute cannabinoid exposure inhibits basal prolactin release in monkeys and rats, and blocks the prolactin surge that occurs on the day of proestrus or in response to suckling (34).

In addition, exposure to natural cannabis extracts during pregnancy has been correlated with embryotoxicity and specific teratological malformations in rats, hamsters and rabbits (37). Finally, anandamide has been shown to impair pregnancy and embryonic development in mice. However, anandamide has been suggested to have a dual role, with low anandamide levels being associated with implantation and high levels with uterine changes during gestation (37).

\section{EXTRAPOLATION OF ANIMAL DATA TO HUMANS}

Animal studies are important in determining the overall toxicity of compounds such as cannabis and cannabinoids. They allow the use of various animal species, the choice of the route of administration and doses, as well as the duration of the treatment to obtain acute or chronic conditions. Furthermore, it is possible for animal studies to control for confounding factors, and also to allow direct pathological studies of all the organs. 
When it comes to extrapolation of the data to humans, the picture is more complex. Three main approaches based on body weight, body surface area and pharmacokinetic data have been used to extrapolate animal data to humans (2). However, none of these approaches is ideal, and sometimes quite puzzling results are obtained. For example, the lethal dose of THC in nonhuman primates turned out to be five- to 10 -fold higher than that found in rats and dogs (6).

\section{CONCLUSIONS}

More data are needed on the adverse effects of cannabinoids in animals, especially on controversial issues such as their effects on the brain and immune system. However, one should be very careful when interpreting the results and appying them to humans. The best approach to human toxicology rests on the study of human data.

\section{REFERENCES}

1. Ware M, Tawfik VL. Safety issues concerning the medical use of cannabis and cannabinoids. Pain Res Manage 2005;10(Suppl A):31A-37A.

2. Grotenhermen F. Review of unwanted actions of cannabis and THC. In: Grotenhermen F, Russo E, eds. Cannabis and Cannabinoids. New York: The Haworth Integrative Healing Press, 2002:233-47.

3. Joy JE, Watson SJ, Benson JA, eds. Marijuana and Medicine: Assessing the Science Base. Washington, DC: Institute of Medicine, National Academy Press, 1999.

4. Dewey WL. Cannabinoid pharmacology. Pharmacol Rev 1986;38:151-78.

5. Collective authorship. Cannabis: Quels effets sur le comportement et la santé? Inserm Ed. 2001.

6. Ledent C, Valverde O, Cossu G, et al. Unresponsiveness to cannabinoids and reduced addictive effects of opiates in CB1 receptor knockout mice. Science 1999;283:401-4.

7. Thompson GR, Rosenkrantz H, Schaeppi UH, Braude MC. Comparison of acute oral toxicity of cannabinoids in rats, dogs and monkeys. Toxicol Appl Pharmacol 1973;25:363-72

8. House of Lords Select Committee on Science and Technology. Cannabis: The scientific and medical evidence. London: The Stationary Office. 1998.

9. Thompson GR, Fleischman RW, Rosenkrantz H, Braude MC. Oral and intravenous toxicity of delta-9-tetrahydrocannabinol in rhesus monkeys. Toxicol Appl Pharmacol 1974;27:648-65.

10. Phillips RN, Turk RF, Forney RB. Acute toxicity of delta-9. tetrahydrocannabinol in rats and mice. Proc Soc Exp Biol Med 1971;136:260-3.

11. Sanudo-Pena MC, Romero J, Seale GE, et al. Activational role of cannabinoids on movement. Eur J Pharmacol 2000;391:269-74.

12. Adams IB, Martin BR. Cannabis: Pharmacology and toxicology in animals and humans. Addiction 1996;91:1585-614.

13. Patel S, Hillard CJ. Cannabinoid CB1 receptor agonists produce cerebellar dysfunction in mice. J Pharmacol Exp Ther 2001;297:629-37

14. DeSanty KP, Dar MS. Cannabinoid-induced motor incoordination through the cerebellar $\mathrm{CB}(1)$ receptor in mice. Pharmacol Biochem Behav 2001;69:251-9.

15. Leweke FM. Acute effects of cannabis and the cannabinoids. In: Grotenhermen F, Russo E, eds. Cannabis and Cannabinoids. New York: The Haworth Integrative Healing Press, 2002:249-56. 16. Iversen L. Cannabis and the brain. Brain 2003;126:1252-70.
17. Trouve R, Nahas G. Cardiovascular effects of marihuana and cannabinoids. In: Nahas GG, Sutin KM, Harvey DJ, Agurell S, eds. Marihuana and Medicine. Totowa, New Jeresey: Humana Press, 1999:291-304.

18. Forney RB. Toxicology of marihuana. Pharmacol Rev 1971;23:279-84.

19. Krowicki ZK, Moerschbaecher JM, Winsauer PJ, Digavalli SV, Hornby PJ. Delta9-tetrahydrocannabinol inhibits gastric motility in the rat through cannabinoid CB1 receptors. Eur J Pharmacol 1999;371:187-96

20. Tashkin DP. Marihuana and the lung. In: Nahas GG, Sutin KM, Harvey DJ, Agurell S, eds. Marihuana and Medicine. Totowa, New Jersey: Humana Press, 1999:279-87.

21. Scallet AC. Neurotoxicity of cannabis and THC: A review of chronic exposure studies in animals. Pharmacol Biochem Behav 1991;40:671-6.

22. Mechoulam R, Lichtman AH. Neuroscience. Stout guards of the central nervous system. Science 2003;302:65-7.

23. Carlini EA. Tolerance to chronic administration of Cannabis sativa (marihuana) in rats. Pharmacology 1968;1:135-42.

24. Swift W, Hall W. Cannabis and dependence. In: Grotenhermen F, Russo E, eds. Cannabis and Cannabinoids. New York: The Haworth Integrative Healing Press, 2002;257-68.

25. Parolaro D, Massi P, Rubino T, Monti E. Endocannaboids in the immune system and cancer. Prostaglandins Leukot Essent Fatty Acids 2002;66:319-32.

26. Cabral GA. Immune system. In: Grotenhermen F, Russo E, eds. Cannabis and Cannabinoids. New York: The Haworth Integrative Healing Press, 2002;279-87.

27. Mishkin EM, Cabral G. Delta-9-tetrahydrocannabinol decreases host resistance to herpes simplex virus type 2 vaginal infection in the B6C3F1 mouse. J Gen Virol 1985;66:2539-49.

28. McCoy KL, Gainey D, Cabral GA. delta 9-Tetrahydrocannabinol modulates antigen processing by macrophages. J Pharmacol Exp Ther 1995;273:1216-23.

29. Munson AE, Harris LS, Friedman MA, Dewey WL, Carchman RA. Antineoplastic activity of cannabinoids. J Natl Cancer Inst 1975;55:597-602.

30. Zhu LX, Sharma S, Stolina M, et al. Delta-9-tetrahydrocannabinol inhibits antitumor immunity by a CB2 receptor-mediated, cytokine-dependent pathway. J Immunol 2000;165:373-80.

31. Chan PC, Sills RC, Braun AG, Haseman JK, Bucher JR. Toxicity and carcinogenicity of delta 9-tetrahydrocannabinol in Fischer rats and B6C3F1 mice. Fundam Appl Toxicol 1996;30:109-17.

32. Guzman M. Cannabinoids: Potential anticancer agents. Nat Rev Cancer 2003;3:745-55.

33. Bifulco M, Di Marzo V. Targeting the endocannabinoid system in cancer therapy: A call for further research. Nat Med 2002;8:547-50.

34. Murphy LL. Hormonal system and reproduction. In: Grotenhermen F, Russo E, eds. Cannabis and Cannabinoids. New York: The Haworth Integrative Healing Press, 2002:289-97.

35. Zimmerman AM, Zimmerman S, Raj AY. Effects of cannabinoids on spermatogenesis in mice. In: Nahas GG, Sutin KM, Harvey DJ, Agurell S, eds. Marihuana and Medicine. Totowa, New Jersey: Humana Press, 1999:347-57.

36. Smith CG, Moore CE, Besch NF, Besch PK. The effects of marihuana (Delta-9-THC) on the secretion of sex hormones in the mature male rhesus monkey. Clin Chem 1976;22:1184.

37. Maccarrone M, Falciglia K, Di Rienzo, Finazzi-Agro A. Endocannaboids, hormone-cytokine networks and human fertility. Prostaglandins Leukot Essent Fatty Acids 2002;66:309-17.

38. Martin BR, Compton DR, Thomas BF, et al. Behavioral, biochemical and molecular modeling evaluations of cannabinoid analogs. Pharmacol Biochem Behav 1991;40:471-8. 


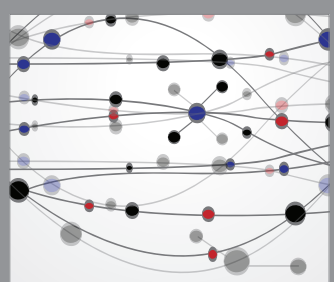

The Scientific World Journal
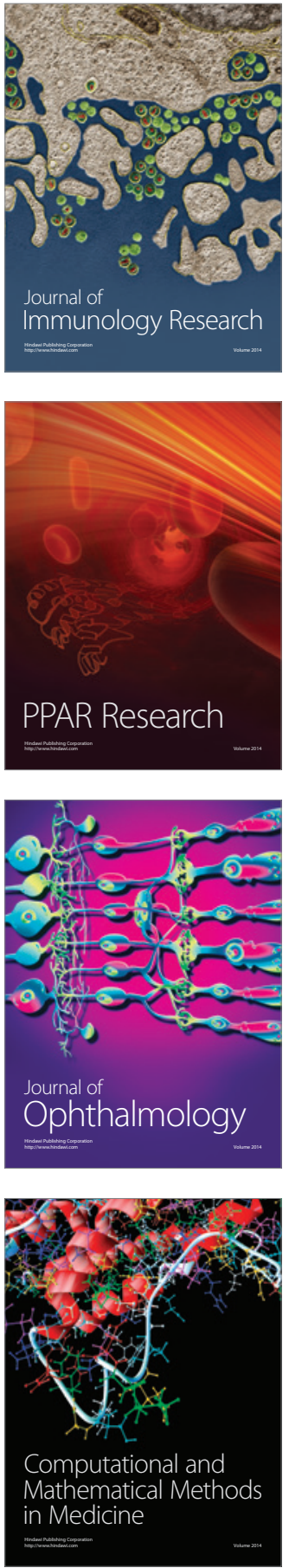

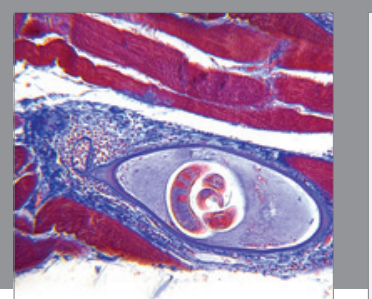

Gastroenterology Research and Practice

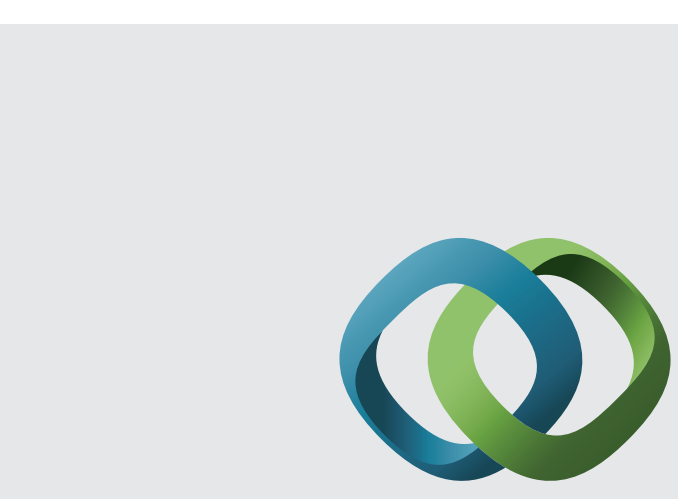

\section{Hindawi}

Submit your manuscripts at

http://www.hindawi.com
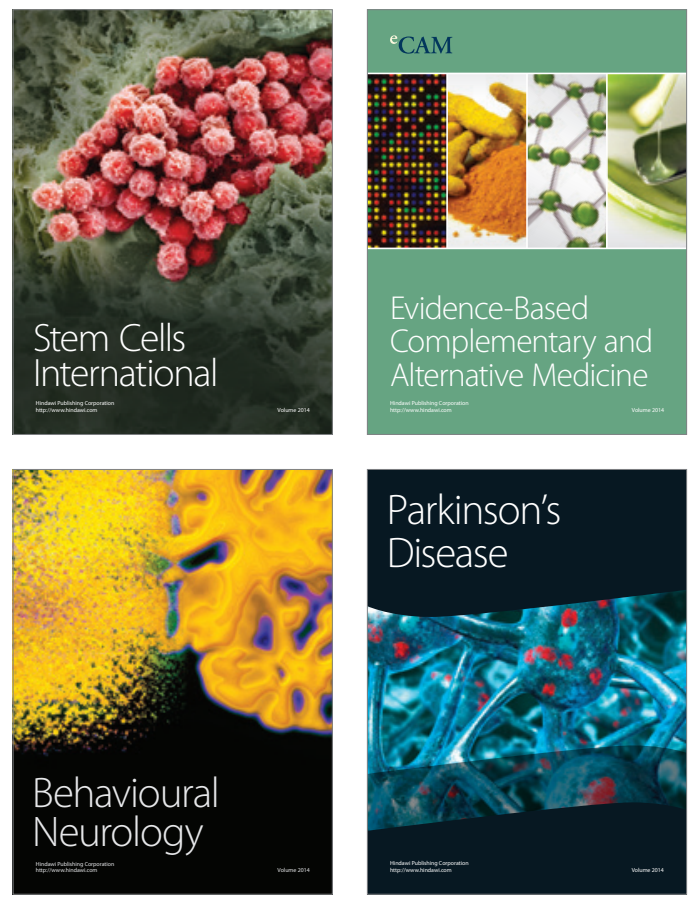
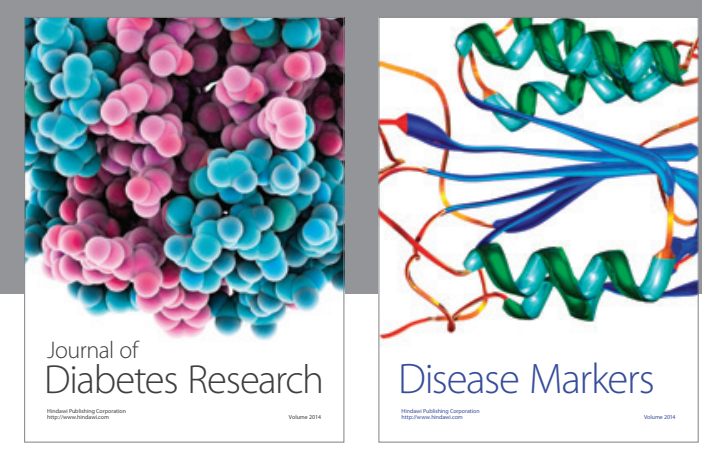

Disease Markers
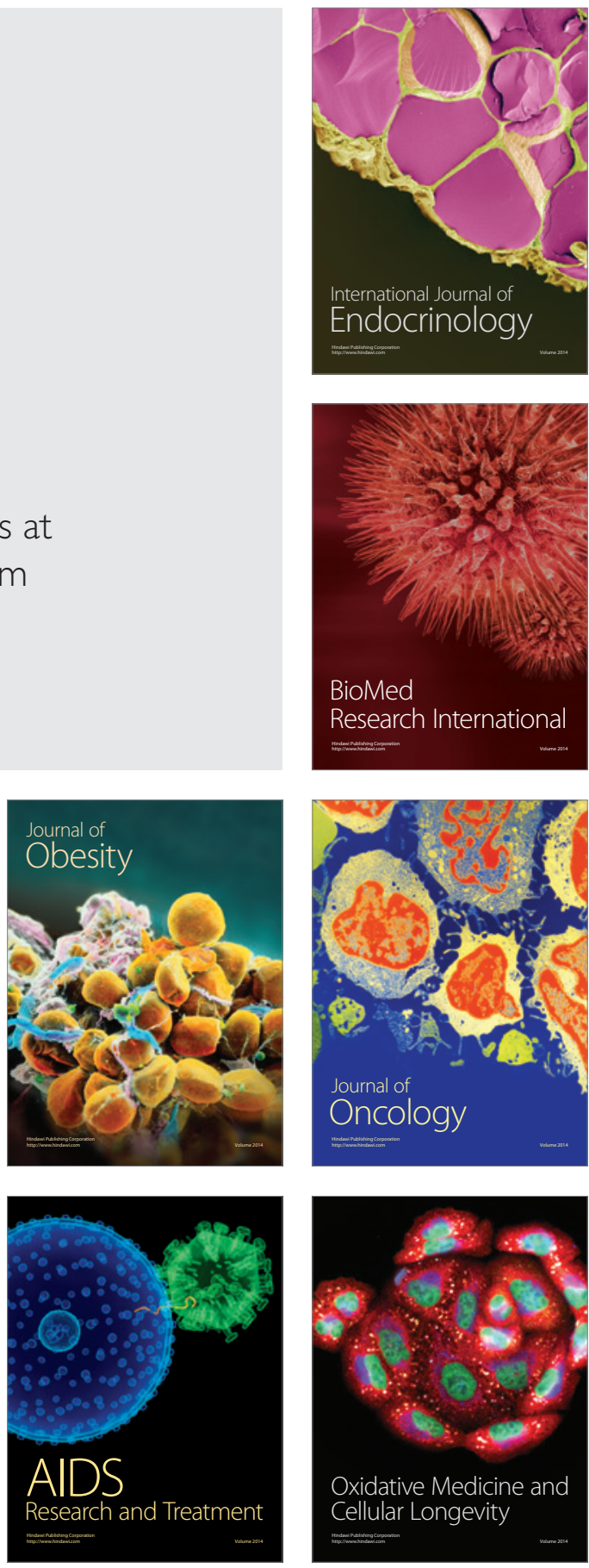